\title{
LAJU PERTUMBUHAN IKAN NILA (Oreocromis niloticus) YANG DIPELIHARA DENGAN MENGGUNAKAN SISTEM BIOFLOK DI KABUPATEN SUMBA TIMUR
}

\author{
The Growth of Tilapia (Oreocromis niloticus) Using The Biofloc System
}

\author{
Ridwan Meldi Nite ${ }^{1)}$, Nurbety Tarigan ${ }^{1 *}$ \\ ${ }^{1)}$ Program Studi Teknologi Hasil Perikanan, Fakultas Sains dan Teknologi, Universitas \\ Kristen Wira Wacana Sumba, Waingapu, 87116, Indonesia \\ *korespondensi: nurtarigan@unkriswina.ac.id
}

Diterima : 01 April 2021; Disetujui : 29 April 2021

\begin{abstract}
Biofloc technology is a fish culture technology based on the principle of assimilation of inorganic nitrogen (ammonia, nitrite and nitrate) by the microbial community (heterotrophic bacteria) in culture media which can then be used by the cultivated organism as a food source. The use of probiotics in aquaculture is used to control microbes in the water, in the digestive tract of the host, improve the quality of the aquatic environment through the process of biodegradation. Biofloc technology is expected to minimize the cost of feed most spent during tilapia cultivation. The purpose of this activity is to evaluate the growth of tilapia (Oreocromis niloticus) using the biofloc system. The method used is an experimental method. All parameters measured were analyzed descriptively. The results of the growth rate of tilapia maintained for 32 days using the biofloc system are a life-passing rate of $100 \%$, and a specific growth rate of 5.23\% with a body weight of 35 grams and a body length of $9.6 \mathrm{~cm}$. Based on this, the biofloc system can provide a maximum fish growth rate.
\end{abstract}

Keywords: Oreocromis niloticus, the growth rate, biofloc system

\begin{abstract}
ABSTRAK
Teknologi bioflok merupakan teknologi budidaya ikan yang didasarkan pada prinsip asimilasi nitrogen anorganik (amonia, nitrit dan nitrat) oleh komunitas mikroba (bakteri heterotrof) dalam media budidaya yang kemudian dapat dimanfaatkan oleh organisme budidaya sebagai sumber makanan. Pengunaan probiotik dalam budidaya perairan dimanfaatkan untuk mengendalikan mikroba dalam air, dalam saluran pencernaan inang, memperbaiki kualitas lingkungan perairan melalui proses biodegradasi.Teknologi bioflok diharapkan dapat meminimalisir biaya pakan yang paling banyak dikeluarkan selama budidaya ikan nila. Adapun tujuan dilakukan kegiatan ini adalah untuk mengevaluasi pertumbuhan ikan nila (oreocromis niloticus) dengan menggunakan sistem bioflok. Metode yang digunakan adalah metode eksperimen. Seluruh parameter yang diukur dianalisis secara deskriptif. Adapun hasil laju pertumbuhan ikan nila yang dipelihara selama 32 hari menggunakan sistem bioflok yakni tingkat kelulusan hidup sebesar $100 \%$, dan laju pertumbuhan spesifik sebesar $5,23 \%$ dengan bobot tubuh 35 gram dan panjang tubuh 9,6 cm. Berdasarkan hal tersebut bahwa sistem bioflok dapat memberikan laju pertumbuhan ikan yang maksimal.
\end{abstract}

Kata kunci: Ikan Nila, laju pertumbuhan, sistem bioflok

\section{PENDAHULUAN}

Sumba Timur merupakan salah satu kabupaten yang ada di Provinsi Nusa Tenggara Timur. Kabupaten Sumba Timur memiliki potensi lahan yang cukup luas, lahan tersebut dapat dimanfaatkan sebagai usaha budidaya ikan air tawar. Budidaya ikan air tawar di Sumba Timur masih dilakukan secara tradisional (Tarigan et al. 2020). Salah satu teknologi budidaya ikan yang bisa dilakukan di Sumba Timur adalah dengan menggunakan teknologi bioflok.

Teknologi bioflok merupakan teknologi budidaya ikan yang didasarkan prinsip asimilasi nitrogen anorganik (amonia, nitrit dan nitrat) oleh komunitas mikroba (bakteri heterotrof) dalam media budidaya yang 
dapat dimanfaatkan oleh organisme budidaya sebagai sumber makanan. Pengunaan probiotik dalam budidaya perairan dimanfaatkan untuk mengendalikan mikroba dalam air, dalam saluran pencernaan inang, memperbaiki kualitas lingkungan perairan melalui proses biodegradasi (Aslamyah, 2011).

Teknologi bioflok diharapkan dapat meminimalisir biaya pakan yang paling banyak dikeluarkan selama budidaya ikan nila merah yaitu $60-70 \%$ dari biaya produksi. Berdasarkan hasil penelitian Puspitasari et al. (2020) bahwa penerapan teknologi bioflok dapat meminimalisir biaya pakan yang harganya relatif tinggi. Prinsip dari teknologi bioflok adalah untuk menumbuhkan mikroorganisme terutama bakteri heterotrof di air untuk menyerap komponen polutan, amonia pada air kolam. Sukardi et al. (2018) juga melaporkan bahwa teknologi bioflok merupakan salah satu alternatif dalam meminimalisir masalah limbah budidaya ikan air tawar. Bioflok dapat memanfaatkan limbah nitrogen anorganik dari sisa pakan dan kototran ikan sebagai pakan alami bagi ikan sehingga dapat meningkatkan pertumbuhan dan efisiensi pakan ikan.

Sampai saat ini, di Sumba Timur belum pernah dilakukan budidaya ikan nila menggunakan sistem teknologi bioflok. Berdasarkan hal tersebut masih perlu dilakukan penelitian tentang laju pertumbuhan ikan nila (oreocromis niloticus) dengan menggunakan sistem bioflok. Tujuan kegiatan ini adalah untuk mengevaluasi pertumbuhan ikan nila (oreocromis niloticus) yang dipelihara dengan menggunakan sistem bioflok.

\section{METODE PENELITIAN}

\section{Waktu dan Tempat}

Kegiatan ini dilakukan pada bulan Januari- Februari 2021 bertempat di Kolam Percobaan Kelurahan Malumbi Sumba timur.

\section{Bahan dan Alat}

Bahan yang digunakan dalam penelitian adalah ikan nila merah, telur ayam, micin, pakan, dan probiotik EM-4 sedangkan alat yang digunakan adalah kolam terpal bulat yang berukuran diameter $1,5 \mathrm{~m}$ dengan tinggi $90 \mathrm{~cm}$, batu aerasi, selang aerator, mortal, botol kaca, timbangan digital, dan alat tulis.

\section{Metode Penelitian}

Metode yang digunakan pada kegiatan ini adalah metode eksperimen. Seluruh parameter yang diukur dianalisis secara deskriptif. Adapun parameter pengukuran dalam kegiatan ini adalah sebagai berikut:

$$
\text { kelulusan hidup ikan }(\mathrm{SR})=\frac{N t}{\mathrm{No}} \times 100 \%
$$

Keterangan:

No : Jumlah ikan yang hidup awal penelitian

$\mathrm{Nt}$ : Jumlah ikan yang hidup diakhir penelitian

$$
\mathrm{SGR}=\frac{W t-W o}{\mathrm{t}} \times 100 \%
$$

Keterangan:

SGR :Laju pertumbuhan spesifik

$\mathrm{Wt}$ : Bobot Biomassa ikan pada akhir penelitian

Wo : Bobot Biomassa ikan pada awal penelitian

$\mathrm{T}$ : lama pemeliharaan

$$
\mathrm{Pm}=\mathrm{Lt}-\mathrm{Lo}
$$

Keterangan:

$\mathrm{Pm}$ :Pertumbuhan panjang mutlak (cm)

Wt : Berat rata-rata akhir penelitian

Wo : berat rata-rata awal penelitian

\section{Prosedur Kerja}

\section{Persiapan Kolam Pemeliharaan}

Kolam yang digunakan adalah kolam terpal bulat. Adapun persiapan yang dilakukan adalah merakit komponen-komponen kolam yang terbuat dari besi. Selanjutnya, dilakukan pula pemasangan Wire Mess yang 
berdiameter $1,5 \mathrm{~m}$ dan tinggi $90 \mathrm{~cm}$ selain itu dilakukan juga pemasangan pipa PVC untuk saluran outlet dan inlet pada kolam.

\section{Persiapan Kultur Bakteri}

Kultur bakteri dilakukan dengan cara menyiapkan satu buah botol yang berukuran besar sebagai wadah kultur. Selanjutnya menyiapkan satu botol probiotik, satu butir telur serta micin sebanyak dua sendok. Setelah dilakukan persiapan alat dan bahan pada kultur bakteri makan dilanjutkan proses pemasukan bahan. Proses pemasukan bahan dengan cara memasukan telur, micin dan bakteri probiotik (sebagai stater) sebanyak $100 \mathrm{ml}$. Seluruh bahan dimasukan ke dalam botol kemudian ditambahkan air kolam sebanyak satu liter kemudian botol ditutup secara rapat dan didiamkan selama 1-2 hingga air berwarna merah.

\section{Kultur Bakteri}

Proses kultur bakteri dilakukan dengan cara memperbanyak bakteri yang berasal dari probiotik. Proses memperbanyak bakteri dengan cara menyiapkan botol plastik sebagai wadah kultur, bakteri probiotik (sebagai stater), satu butir telur, micin dan air kolam sebagai media kultur. Selanjutnya masukan semua bahan ke dalam wadah kultur kemudian tutup dengan rapat dan diamkan selama 3 hari sampai air di dalam botol berwarna merah.

\section{Penebaran Bakteri}

Penebaran bakteri dimasukan kedalam air kolam dilakukan dengan takaran 100 $\mathrm{ml} / \mathrm{M}^{3}$ kemudian air didiamkan selama kurang lebih 24 jam sebelum penebaran benih ikan nila. Penebaran bakteri dilakukan setiap semingu sekali selama pemeliharaan. Hal ini bertujuan untuk menambah populasi bakteri didalam air kolam yang nantinya akan dijadikan pakan alami pada benih ikan nila.

\section{Penebaran benih ikan}

Penebaran benih dilakukan setelah dilakukan penebaran bakteri didalam kolam. Penebaran benih ikam dilakukan pada pagi hari, hal ini bertujuan agar tidak menimbulkan stress pada benih ikan nila. Benih ikan nila ditebar dengan cara plastik packing didiamkan selama 15 menit diatas air kolam. Selanjutnya, plastik packing ikan dibuka dan diarahkan ke kolam kemudian dibiarkan benih ikan keluar dari mulut plastik secara perlahanlahan kedalam air kolam. Jumlah benih ikan yang ditebar berjumlah 200 ekor.

\section{Pemberian pakan}

Pakan yang diberikan pada benih ikan nila selama pemeliharaan adalah berupa pellet halus. Pemberian pakan dilakukan 3 kali sehari pada pukul 08:00, 12:00 dan 16:00 WITA. Pemberian pakan dilakukan secara ad libitum. Pemberian pakan dilakukan selama 30 hari.

\section{Sampling}

Sampling dilakukan setelah dilakukan penebaran benih didalam kolam. Sampling dilakukan sebelum pemeliharaan ikan dan akhir dari pemeliharaan ikan. Pada kegiatan sampling dilakukan sebelum dan sesudah peliharan yakni pengukuran bobot dan panjang pada benih ikan nila pengukuran bobot dilakukan dengan menggunakan timbangan digital selanjutnya pengukuran panjang diukur dengan menggunakan penggaris. Sampling dilakukan pada sore hari sehingga dapat menimalisir tingkat stress pada ikan.

\section{HASIL DAN PEMBAHASAN}

Hasil pengamatan penelitian ini pada parameter yang diukur selama pemeliharaan ikan nila menggunakan sistem bioflok dapat dilihat pada Tabel 1. 
Tabel 1. Nilai (SGR), Laju pertumbuhan spesifik (SR), dan pertumbuhan panjang pada ikan nila dengan menggunakan sistem bioflok

\begin{tabular}{lcc}
\hline \multicolumn{1}{c}{ Parameter } & $\begin{array}{c}\text { Awal } \\
\text { penelitian }\end{array}$ & $\begin{array}{c}\text { Akhir } \\
\text { penelitian }\end{array}$ \\
\hline SR (\%) & 100 & 100 \\
SGR (\%) & - & 5,23 \\
\hline
\end{tabular}

\section{Tingkat kelulusan hidup ikan (SR)}

Tingkat kelangsungan hidup merupakan suatu nilai perbandingan antara jumlah organisme awal saat penebaran yang dinyatakan dalam bentuk persen dimana semakin besar nilai persentase menunjukan semakin banyak organisme yang hidup selama pemeliharaan (Effendi 2002). Berdasarkan Tabel 1. hasil pengamatan menunjukkan bahwa tingkat kelulusan hidup ikan nila pada awal dan akhir pemeliharaan sebesar $100 \%$. Hal ini disebabkan karena adanya bakteri asam laktat pada sistem bioflok sehingga mempenagruhi laju kelulusan hidup ikan. Hal yang sama juga dilaporkan oleh Tarigan et al. (2020) yang mealporkan bahwa tingkat kelangsungan ikan mas sebesar $100 \%$ dengan pemberian probiotik dalam pakan.

\section{Pertumbuhan Berat Mutlak}

Hasil pengamatan laju pertumbuhan berat harian pada ikan nila yang diukur pada minggu ke 0, 1,2,3 dan 4 disajikan pada Gambar 1. Berdasarkan Gambar tersebut dapat dilihat bahwa bobot tubuh ikan selama pemeliharaan mengalami peningkatan setiap hari pengamatan. Pada pengamatan minggu ke-0 panjang ikan berkisar 10 gram, pada minggu ke-1 mengalami peningkatan menjadi 15 gram sedangkan pada minggu 2,3 dan 4 terus mengalami peningkatan sebesar 25 gram, 30 gram dan 35 gram. Meningkatnya pertumbuhan panjang pada ikan disebabkan karena adanya pemberian probiotik sebagai pakan alami pada kolam bioflok.

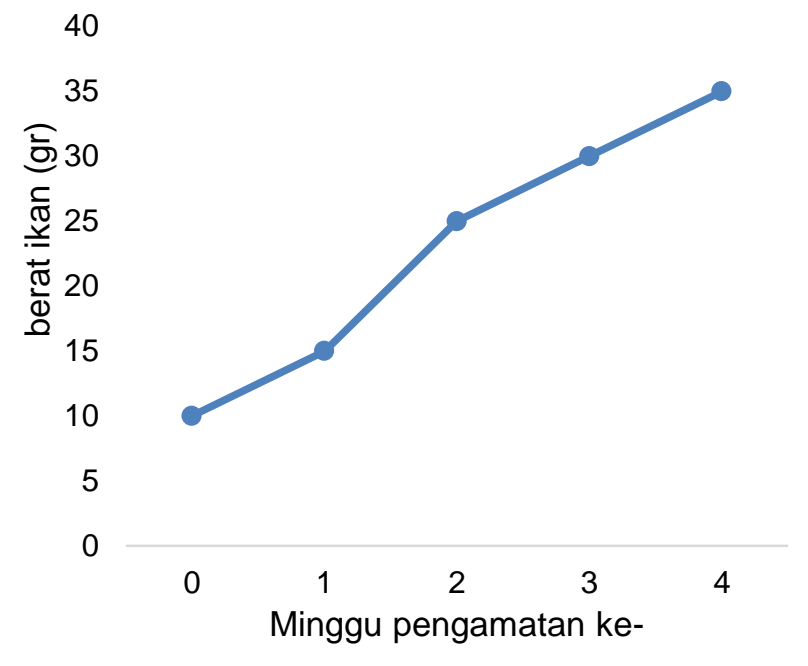

Gambar 1. Penambahan bobot tubuh ikan nila pada pengamatan minggu ke $0,1,2,3$ dan 4 selama pemeliharaan

Hal ini sesuai dengan hasil penelitian Noviana et al. (2014) yang menyatakan bahwa probiotik dalam pakan dapat meningkatkan jumlah bakteri mukosa usus dan pencernaan pada ikan nila sehingga efektif dalam meningkatkan pertumbuhan dan berat ikan nila. Hal yang sama juga dilaporkan oleh Tarigan et al. (2019) bahwa bakteri yang ada dalam sistem bioflok akan mengandung mikroba yang bersifat menguntungkan ikan sehingga dapat meningkatkan daya cerna penyerapan nutrisi dan mempernagruhi pertumbuhan ikan.

\section{Pertumbuhan Panjang Mutlak}

Hasil pengamatan laju pertumbuhan panjang harian pada ikan nila yang diukur pada minggu ke $0,1,2,3$, dan 4 disajikan pada Gambar 2.

Berdasarkan gambar 2. dapat dilihat bahwa bobot tubuh ikan selama pemeliharaan mengalami peningkatan setiap hari pengamatan. Pada pengamatan minggu ke-0 panjang ikan berkisar $7 \mathrm{~cm}$, pada minggu ke-1 mengalami sedikit peningkatan menjadi $7,6 \mathrm{~cm}$ sedangkan pada minggu 2,3 
dan 4 terus mengalami peningkatan sebesar $8,4,8,7$ dan $9,6 \mathrm{~cm}$.

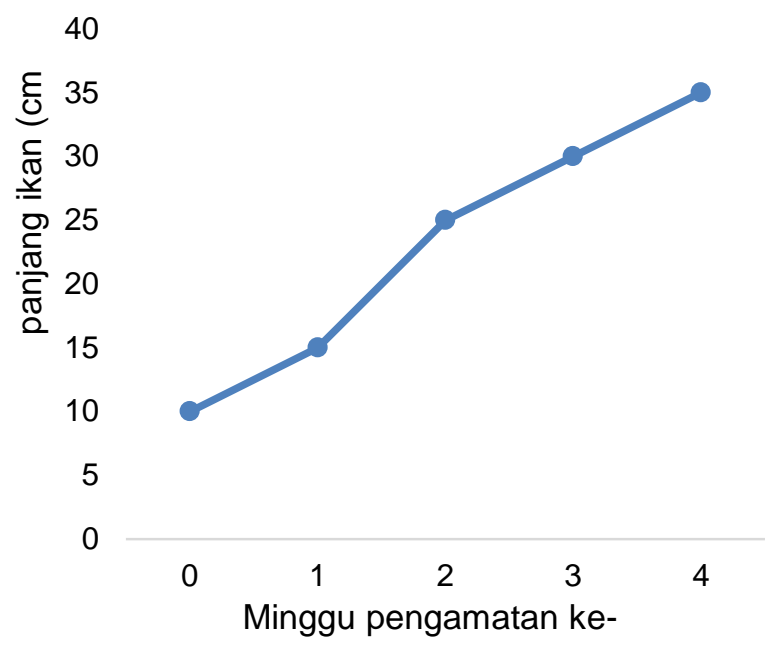

Gambar 2. Penambahan panjang tubuh ikan nila pada pengamatan minggu ke $0,1,2,3$ dan 4 selama pemeliharaan

Meningkatnya pertumbuhan panjang pada ikan disebabkan karena adanya pemberian probiotik pada kolam bioflok. Hal ini sesuai dengan hasil penelitian Tarigan et al. (2019) melaporkan bahwa penggunan probiotik sebagai pakan dapat meningkatkan pertumbuhan panjang pada ikan. Selanjutnya hasil penelitian Ahmadi (2012) juga melaporkan bahwa adanya baketeri pada sistem bioflok akan menyebabkan aktivitas baketri akan bekerja secara maksimal dan proses penyerapan makanan pada ikan menjadi maksimal sehingga proses pertumbuhan ikan semakin baik.

\section{KESIMPULAN}

Laju pertumbuhan ikan nila yang dipelihara menggunakan sistem bioflok selama pemeliharaan 32 hari menghasilkan kelulusan hidup ikan sebesar $100 \%$ dan laju pertumbuhan spesifik sebesar 5,23\% dengan bobot tubuh 35 gram dan panjang tubuh $9,6 \mathrm{~cm}$.

\section{UCAPAN TERIMA KASIH}

Ucapan terima kasih kepada dosen Nurbety Tarigan yang telah banyak membantu selama kegiatan ini.

\section{DAFTAR PUSTAKA}

Ahmadi, H., N. Iskandar \& Kurniawati. 2012. Pemberian probiotik dalam pakan terhadap pertumbuhan lele sangkuriang (Clarias gariepinus) pada pendederan II. Jurnal Perikanan dan Kelautan. 3 (4): 2088-3137.

Aslamyah, S. 2011. kualitas Lingkungan Dan Aktivitas Enzim Pencernaan Udang Vanamai (Litopenaeus vannamei) Pada Berbagai Konsentrasi Probiotik Bioremendasi-Bacillus sp. Fish Scientiae. 1(2) :161-178.

Noviana, P. \& Pinandoyo. 2014. Pengaruh pemberian probiotik dalam pakan buatan terhadap tingkat konsumsi pakan dan pertumbuhan benih ikan nila (Oreochromis niloticus). Journal Aquacultural Management and Technology. 3 (4): 183-190

Pusptasari, A., Isyanto, A. Y., \& Aziz, S. 2020. Penerapan Teknologi Bioflok Pada Budidaya Ikan Nila Didesa Cibuniasih Kabgupaten Tasikmalaya. Abdimas Galuh. 2(2). 175-180.

Tarigan, N., \& Meiyasa, F. 2020. Effectivity of Probiotic Bacteria in Feed on Growth and Survival Rate of Common Carp (Cyprinus carpio). Jurnal Perikanan Universitas Gadjah Mada, 21(2): 85-92.

Tarigan, N., Meiyasa, F., Efruan, G. K., Sitaniapessy, D. A., \& Pati, D. U. 2019. The Application of Probiotics for the Purpose of Growing Catfish (Clarias batrachus) in Malumbi Village, East Sumba. MITRA: Jurnal Pemberdayaan Masyarakat, 3(1) :50-57. 
Sukardi, P., Soedibya, P. H. T. S., \& Pramono, T. B. 2018. Produksi budidaya ikan nila (Oreochromis niloticus) sistem bioflok dengan sumber karbohidrat berbeda. Jurnal AJIE - Asian Journal of Innovation and Entrepreneurship. 03 (02):198203. 